\title{
Rabbits Immunized with Thyroid-stimulating Hormone Produce Autoantiidiotypic Thyroid-stimulating Antibodies
}

Gildon N. Beall, Basil Rapoport, Inder J. Chopra, and Sally R. Kruger

Department of Medicine, Harbor-UCLA Medical Center, Torrance, California 90509; UCLA School of Medicine, Los Angeles, California 90024; and the Veterans Administration, San Francisco, California 94121

\begin{abstract}
We immunized rabbits with thyroid-stimulating hormone (TSH) to investigate the hypothesis that such immunization could result in production of thyroid-stimulating autoantiidiotypic antibodies to anti-TSH. Thyroid-stimulating immunoglobulin (TSI) appeared in the serum of several rabbits after immunization. At $160 \mathrm{~d}$, TSI equivalent to 6-18 $\mu \mathrm{U}$ TSH/1.5 mg IgG was present in two of six human (h)TSH-, two of six hTSH $\beta$ chain-, and two of the four surviving bovine (b)TSH-immunized animals. Control (human serum albumin-immunized rabbits) serum TSI was $4.3 \pm 0.4($ mean $\pm S D)$ at this time. Antiidiotypic antibodies that could bind to monoclonal anti-hTSH were found in the sera of the bTSH-immunized rabbits. The peak TSI activity occurred 3 mo after a TSH booster immunization and declined gradually during subsequent weeks. Evidence that antiidiotypic antibodies to anti-TSH can cause thyroid stimulation strengthens the notion that such antibodies may be the cause of Graves' hyperthyroidism.
\end{abstract}

\section{Introduction}

The hyperthyroidism of Graves' disease is apparently caused by an immunoglobulin that stimulates the thyroid cells to produce thyroid hormones. This material, the thyroid-stimulating immunoglobulin (TSI), ${ }^{1}$ can be detected with bioassays using human thyroid tissue (1). Immunological studies have demonstrated a variety of antibodies in TSI-containing sera. Some of these, apparently including TSI, can bind to the thyroid cellular receptor for thyroid-stimulating hormone (TSH) (2). For these reasons, it has been proposed that TSI is an autoantibody induced by immunization to the TSH receptor.

Studies stimulated by Jerne's network hypothesis (3) have produced abundant evidence for the existence of antiidiotypic antibodies that can present internal images of an antigen. Each antibody is unique in that it can bind a specific antigen. As a result of this uniqueness, each antibody possesses antigenic activity that can stimulate production of antiantibodies (antiidiotypes). If an antiidiotype is directed toward the antigen-

Received for publication 15 June 1984 and in revised form 12 December 1984.

1. Abbreviations used in this paper: bTSH, bovine thyroid-stimulating hormone; eq, equivalents; HB, hypotonic buffer; hSA, human serum albumin; hTSH, human thyroid-stimulating hormone; hTSH $\beta$, human thyroid-stimulating hormone beta chain(s); IB, incubation buffer; $T_{4}$, thyroxine; TM, thyroid membrane(s); TSH, thyroid-stimulating hormone; TSI, thyroid-stimulating immunoglobulin.

J. Clin. Invest.

(c) The American Society for Clinical Investigation, Inc.

0021-9738/85/05/1435/06 $\$ 1.00$

Volume 75, May 1985, 1435-1440 combining site of an antibody, the resulting antiidiotypecombining site may resemble the antigen to which the original antibody was directed. Thus, antibodies to antiinsulin, antiformyl peptides, and antialprenolol have been found to have agonist activities in appropriate bioassays (4-7). These findings suggest an alternate mode of autoimmunization as the source of TSI. TSI may arise as an antiidiotypic antibody (anti-ID) to anti-TSH. The anti-ID could possess an internal image of TSH and thus fit the TSH receptor and act as TSI. If this notion is correct, then TSI-containing sera should also contain anti-TSH. We have been able to demonstrate the binding of ${ }^{125}$ I-human (h)TSH in sera that had been partly depleted of TSI by absorption with thyroid tissue (8). Biro has made similar observations without absorption of TSI $(9,10)$. As a next step in investigation of this hypothesis, we immunized rabbits with TSH. Immunoglobulins in serum obtained from some of the immunized rabbits acted as a thyroid stimulator in the human thyroid cell bioassay. These same sera contained immunoglobulins that specifically bind anti-TSH.

\section{Methods}

Reagents. Highly purified hTSH and hTSH $\beta$ chains (hTSH $\beta$ ) were obtained from the National Pituitary Agency, National Institute of Arthritis, Diabetes, and Digestive and Kidney Diseases, Baltimore, MD. Bovine (b) TSH was Thytropar ${ }^{\circledR}$ obtained from the Armour Pharmaceutical Co., Tarrytown, NY. Phosphate-buffered saline (PBS) was $0.14 \mathrm{M} \mathrm{NaCl}, 0.003 \mathrm{M} \mathrm{KCl}, 0.0012 \mathrm{M} \mathrm{KH}_{2} \mathrm{PO}_{4}$, and $0.008 \mathrm{M}$ $\mathrm{Na}_{2} \mathrm{HPO}_{4}, \mathrm{pH}$ 7.3. Hypotonic buffer (HB) was $5.4 \mathrm{mM} \mathrm{KCl}, 0.44 \mathrm{mM}$ $\mathrm{KH}_{2} \mathrm{PO}_{4}, 0.34 \mathrm{mM} \mathrm{Na}_{2} \mathrm{HPO}_{4}, 1.3 \mathrm{mM} \mathrm{CaCl}_{2}, 0.4 \mathrm{mM} \mathrm{MgSO}_{4}$, and $1 \%$ glucose, pH 7.4. Incubation buffer (IB) was $0.15 \mathrm{M} \mathrm{NaCl}, 0.01 \mathrm{M}$ Tris, $\mathrm{pH} 8.0$, with $0.25 \%$ bovine serum albumin (BSA), $0.02 \%$ sodium azide, and $2 \%$ calf serum.

Immunization. 24 young adult female New Zealand rabbits, 2-2.5 $\mathrm{kg}$, were randomly assigned to four immunization groups and bled before immunization. The groups received the following, respectively: $150 \mu \mathrm{g} \mathrm{hTSH}$ or hTSH $\beta, 1.0 \mathrm{U}$ bTSH, or $500 \mu \mathrm{g}$ human serum albumin (hSA) dissolved in $0.5 \mathrm{ml}$ PBS and emulsified with an equal volume of complete Freund's adjuvant (Calbiochem-Behring Corp., La Jolla, CA). Immunizing injections were given subcutaneously in two sites every $10 \mathrm{~d}$ for a total of six immunizations. A subsequent booster immunization was given on day 160 . Animals were bled every $10 \mathrm{~d}$ for $70 \mathrm{~d}$ and then at days $160,170,225,245,265,315$, and 375 .

TSI. The human thyroid cell bioassay was performed in HB as described previously (11). Crude rabbit IgG preparations were prepared by precipitation of globulins at $33 \%$ saturation of ammonium sulfate. The washed precipitates were dissolved in and dialyzed against HB, using a microdialysis system (Bethesda Research Laboratories, Gaithersburg, MD). IgG content was standardized by measuring optical density at $280 \mathrm{~nm}$ (final assay concentration of $1.5 \mathrm{mg} \mathrm{IgG/ml}$ ). The extinction coefficient at $280 \mathrm{~nm}$ for rabbit $\mathrm{IgG}$ is 1.38 at $1.0 \mathrm{~cm}$ and $1 \mathrm{mg} / \mathrm{ml}$. This method was found to underestimate the IgG concentration measured by radial immunodiffusion (Miles Ames Div., Miles Laboratories Inc., Elkhart, IN). However, because there was a good correlation between the two methods $(r=0.74)$, the optical density 
method was continued throughout the study. The actual concentration of IgG used in the assay was arbitrary and is not critical as long as it is consistent (12). All IgG samples from a particular bleed were measured in the same assay. Values of $2 \mu \mathrm{U}$ TSH equivalents (eq)/1.5 $\mathrm{mg}$ IgG were considered to be positive for TSI activity (11).

Thyroid membrane (TM) binding assay. A method for membraneassociated antigens was adapted for this purpose (13). TM bound to paper disks served as the antigen. The binding of rabbit IgG to the disks was amplified by goat anti-rabbit gamma globulin, which was detected by the binding of ${ }^{125}$ I-staphylococcal protein A. Paper disks 4 $\mathrm{mm}$ in diameter were punched from paper (S\&S 589; Schleicher \& Shuell, Inc., Keene, NH). $2 \mathrm{~g}, \sim 2,000$, of these disks were soaked in distilled water for $1 \mathrm{~h} .40 \mathrm{ml}$ of fresh $5 \% \mathrm{CNBr}$ was then added to the suspension of disks while temperature was maintained at $19^{\circ} \mathrm{C}$ in an ice bath and $\mathrm{pH}$ raised to 10.5 with addition of $1 \mathrm{M} \mathrm{NaOH}$. The reaction between $\mathrm{CNBr}$ and the disks was allowed to proceed for 3 min with stirring. The mixture was then decanted into $300 \mathrm{ml}$ ice-cold $0.005 \mathrm{M} \mathrm{NaHCO}_{3}$; equal quantities of $0.005 \mathrm{M} \mathrm{NaHCO}_{3}$ were used to wash the disks five times. They were then washed four times with acetone at $4^{\circ} \mathrm{C}$ and stored in a desiccator at $4^{\circ} \mathrm{C}$. Human TM were prepared, as described previously, from surgically removed normal tissue (14) and resuspended in $0.1 \mathrm{M} \mathrm{NaHCO}_{3}$ by brief operation of a polytron (Brinkmann Instruments Co., Westbury, NY). Membranes equivalent to $14 \mathrm{~g}$ of thyroid tissue were suspended in $20 \mathrm{ml} 0.1 \mathrm{M}$ $\mathrm{NaHCO}_{3}$ along with $2 \mathrm{~g}$ of $\mathrm{CNBr}$-treated paper disks in a small flask. The mixture was incubated with shaking overnight at $4^{\circ} \mathrm{C}$ and washed twice with $0.1 \mathrm{M} \mathrm{NaHCO}$. The disks were then incubated with shaking with $10 \mathrm{ml} 1.0 \mathrm{M}$ ethanolamine at $\mathrm{pH} 8.2$ for $2 \mathrm{~h}$ at $4^{\circ} \mathrm{C}$. After this preparation, the disks were stored at $4^{\circ} \mathrm{C}$ in IB.

Assays were performed in triplicate using Removastrip ${ }^{\star}$ wells (Dynatech Laboratories, Inc., Dynatech Corp., Alexandria, VA). Disks were placed in the wells and $0.5 \mu \mathrm{l}(50 \mu \mathrm{l}$ of 1:100 dilution in IB) of rabbit serum to be tested was added. Incubation at room temperature continued overnight in a humidified chamber. The disks were then washed five times with $50 \mu \mathrm{l}$ IB. $50 \mu \mathrm{l}$ of a 1:1,000 dilution of goat anti-rabbit immunoglobulin in IB (Antibodies Inc., Davis, CA) was added and allowed to incubate for $2 \mathrm{~h}$ at room temperature. The disks

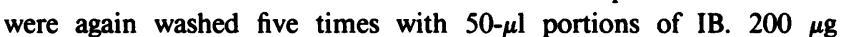
staphylococcal protein A (Pharmacia Fine Chemicals, Div. of Pharmacia Inc., Piscataway, $\mathrm{NJ}$ ) was labeled with $0.5 \mathrm{mCi}{ }^{125} \mathrm{I}-\mathrm{NaI}$ using techniques similar to those described for iodination of TSH. Immunoglobulin binding by the disk was then detected by addition of $50 \mu \mathrm{l}$ of IB containing $50,000 \mathrm{cpm}$ of ${ }^{125} \mathrm{I}$-staphylococcal protein A. After another series of five washings, the wells containing the disks were counted in a gamma counter. Controls included disks without membranes and normal rabbit serum.

Anti-TSH. Highly purified hTSH (National Pituitary Agency) was iodinated as described by Pekary et al. (15). Anti-TSH activity in the rabbit sera was assessed by diluting immune serum with $10 \%$ normal rabbit serum so that $0.002-1.0 \mu \mathrm{l}$ of immune serum in $100 \mu \mathrm{l}$ of $10 \%$ normal rabbit serum in PBS was incubated with $20,000 \mathrm{cpm}{ }^{125} \mathrm{I}-$ hTSH in PBS overnight at $4^{\circ} \mathrm{C}$. TSH-anti-TSH complexes were then precipitated with an excess $(20 \mu$ l of goat anti-rabbit gamma globulin (Antibodies Inc.) overnight at $4^{\circ} \mathrm{C}$. The precipitates were washed with $0.5 \mathrm{ml}$ cold PBS containing $0.01 \%$ Triton X-100 (Eastman Kodak Co., Rochester, NY). After centrifugation, the supernatants were aspirated and the precipitates counted in a gamma counter. The results of these binding assays for each antiserum were plotted on semilog paper. The amount of serum that would bind $50 \%$ of the added ${ }^{125}$ I-hTSH was read from the curve.

Assay for antiidiotypic antibodies in anti-TSH. The method used was a modification of that described by Geha (16). A monoclonal mouse anti-hTSH purified chromatographically to contain only IgG $_{1}$ protein (generously provided by Dr. W. D. Odell, University of Utah School of Medicine, Salt Lake City, UT) was labeled with ${ }^{125}$ I and absorbed with formalinized staphylococci (IgGsorb; The Enzyme Center, Boston, MA) to remove the small amount of $\mathrm{IgG}_{1}$ that bound easily to protein $\mathrm{A}$.
To remove rheumatoid factor activity, serum from the immunized rabbits was absorbed $1 \mathrm{~h}$ at room temperature with mouse immunoglobulins (Miles Scientific Div., Miles Laboratories Inc., Naperville, IL) bound to Affigel 10 (Bio-Rad Laboratories, Richmond, CA). Triplicate aliquots of $100 \mu \mathrm{l}$ of absorbed rabbit serum were placed in $400-\mu 1$ microcentrifuge tubes together with $100 \mu \mathrm{l}$ of ${ }^{125} \mathrm{I}$-monoclonal mouse anti-TSH and incubated overnight at $4^{\circ} \mathrm{C}$. Formalinized staphylococci, $100 \mu \mathrm{l}$ of a $10 \%$ suspension, was then added to each tube. The tubes were incubated at $20^{\circ} \mathrm{C}$ for $1 \mathrm{~h}$ and then centrifuged for 3 min (Microfuge; Beckman Instruments, Inc., Fullerton, CA). The supernatants were removed and the precipitates washed three times with PBS containing $1 \%$ BSA and $0.5 \%$ Tween 20 . The sedimented radioactivity bound to staphylococci was assayed with a gamma spectrometer.

The proportion bound was determined by comparison with the total precipitable iodinated immunoglobulin in tubes containing ${ }^{125}$ Ianti-TSH, goat anti-mouse IgG (Miles Scientific Div., Miles Laboratories Inc.) and formalinized staphylococci. Binding of ${ }^{125}$ I-anti-TSH to normal rabbit serum was subtracted from that found with immunized rabbit serum to give net binding. Specificity was assured by comparison of binding of rabbit globulins with ${ }^{125}$ I mouse myeloma $\mathrm{IgG}_{1}$ (Miles Scientific Div., Miles Laboratories Inc.).

Ultracentrifugation. 1-ml aliquots of rabbit serum dialyzed against $0.1 \mathrm{M}$ glycine $\mathrm{HCl}, \mathrm{pH} 2.2$, were placed on a gradient of $2 \mathrm{ml}$ of $20 \%$ sucrose and $2 \mathrm{ml}$ of $10 \%$ sucrose in $0.1 \mathrm{M}$ glycine $\mathrm{HCl}, \mathrm{pH} 2.2$. Control aliquots dialyzed vs. PBS were centrifuged on sucrose in PBS. Centrifugation was performed in a model L265B with SW 50.1 head (Spinco Div., Beckman Instruments, Inc.) at $50,000 \mathrm{rpm}$ for $18 \mathrm{~h}$. The 20 and $10 \%$ sucrose fractions were recovered, dialyzed free of sucrose, and then prepared for TSI or antiidiotype assay in the usual fashion. $2 \mathrm{mg} / \mathrm{ml}$ normal rabbit IgG was added to the $10 \%$ sucrose fractions before TSI assay.

Measurement of serum thyroxine $\left(T_{4}\right)$ concentration. $T_{4}$ was measured in rabbit sera by a radioimmunoassay described previously (17). Charcoal-treated (iodothyronine-free) rabbit serum was added to tubes for the standard curve to render protein concentration equal to that in test samples. Radioactive $T_{4}$ bound to anti- $T_{4}$ antibody was precipitated by adding to the reaction mixture (volume, $0.5 \mathrm{ml}$ ) $1 \mathrm{ml}$ of a solution containing $1 \mathrm{mg}$ bovine gamma globulin and $20 \%$ polyethylene glycol (carbowax 6000).

\section{Results}

TSI appeared in the serum of many of the rabbits after immunization with TSH (Fig. 1). At $160 \mathrm{~d}$, two out of six animals immunized with hTSH, two out of six immunized with $\operatorname{hTSH} \beta$, and two out of the four surviving animals immunized with bTSH had TSI activities of 6-18 $\mu \mathrm{U}$ TSH eq. These values were $>2$ SD above the mean of the hSAimmunized animals, $4.3 \pm 0.4 \mu \mathrm{U}$ TSH eq. A similar difference in TSI levels among groups persisted at the bleedings on days 170,225 , and 245 . On day 160 , six out of $16 \mathrm{TSH}$-immunized rabbits had TSI.

Evidence for antiidiotypic antibodies to hTSH was found in the serum of rabbits immunized with bTSH at the same time that TSI activity was detected in those sera. There was a striking correlation between the two activities $(r=0.97$ for the bleedings of day 160 and 0.95 for the bleedings on day 170). Little or no antiidiotypic activity to hTSH could be detected in the serum from the rabbits immunized with hTSH or hTSH subunits. Animals immunized with hTSH developed antibodies that could bind hTSH, but this activity did not correlate with the TSI activity found in such sera.

The rabbits immunized with hSA developed immunoglobulins that could bind the iodinated monoclonal anti-TSH. This binding was specific for the antibody concerned, since there 

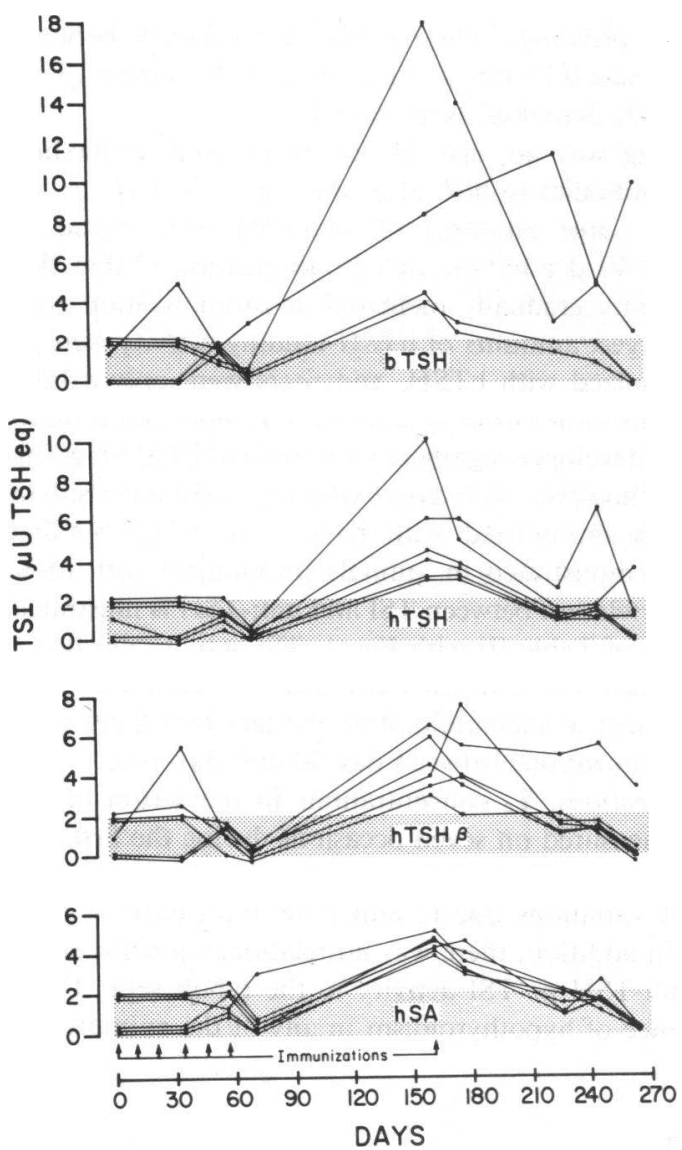

Figure 1. TSI activity in the serum of each of the rabbits is shown during the $270 \mathrm{~d}$ of the experiment. Arrows indicate immunizations. Values of $2.0 \mu \mathrm{U}$ TSH eq or more are considered positive for thyroid stimulation. Peak activity is seen at $160 \mathrm{~d}, 3$ mo after the sixth immunization with TSH. After another immunization the activity gradually declined.

was no binding by such sera to mouse $\mathrm{IgG}_{1}$ or to a mouse $\mathrm{IgG}_{1}$ monoclonal anti-IgE. This binding by anti-hSA-containing sera did not correlate with the small amounts of TSI activity sometimes found in such sera (Fig. 2).

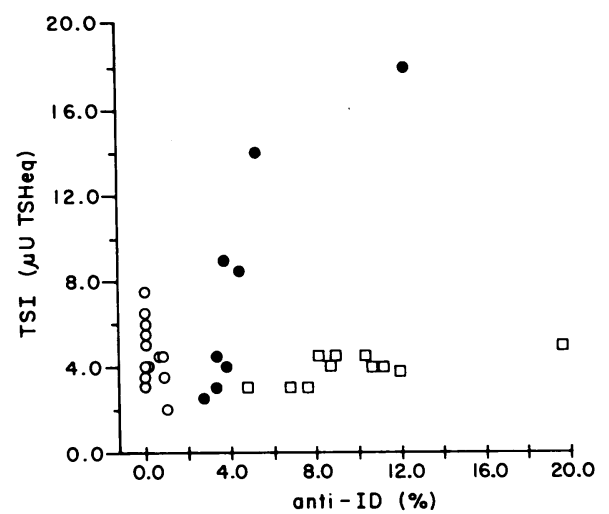

Figure 2. TSI in microunits of TSH equivalents is plotted on the ordinate, and antiidiotypic activity to anti-TSH is plotted on the abscissa for the 160- and 170-d bleedings of each rabbit. (๑), Rabbits immunized with bTSH; (O), rabbits immunized with hTSH or hTSH $\beta$; (ם), rabbits immunized with hSA.
Serum from rabbits immunized with hSA was found to have small amounts of thyroid-stimulating activity in some bleedings. This phenomenon seemed at least partly related to immunization, since normal rabbit or human IgG had no such effect. There was a distinct correlation of the stimulatory activity of serum from these hSA-immunized control animals with the sensitivity to TSH of the thyroid cells used for the specific assay (Spearman rank correlation coefficient, $r=0.86$, $P<0.01)$.

TSI activity reached a maximum for most animals on day 160 , which was $110 \mathrm{~d}$ after the most recent immunization. From that point, TSI activities gradually declined, possibly because of the booster immunization given on day 160 .

When two sera containing large amounts of TSI activity were tested at varying concentrations, a linear dose-response relationship was found in the thyroid cell bioassay (Fig. 3). The total amount of rabbit globulin was equalized by addition of varying amounts of normal rabbit serum globulin.

We considered the possibility that immune complexes of TSH-anti-TSH could be responsible for thyroid stimulation and the binding of monoclonal anti-TSH to an immunoglobulin. The rabbit sera contained anti-TSH and it may be proposed that TSH is derived from the immunization or secreted by the rabbit's pituitary. It is conceivable that such complexes might remain intact through the globulin precipitation steps of the TSI assay. To investigate this possibility, TSI-containing sera were dialyzed against either $0.1 \mathrm{M}$ glycine $\mathrm{HCl}, \mathrm{pH} 2.2$ (to dissociate immune complexes), or PBS (as a nonacidified control) and then ultracentrifuged on sucrose gradients. Gradient fractions were dialyzed free of sucrose and assayed for TSI or antiidiotypic activity. ${ }^{125}$ I-TSH was mixed with an appropriate quantity of anti-TSH and similarly dialyzed and centrifuged to provide a control. As seen in Table I, all of the TSI, and almost all of the anti-ID activity from nonacidified rabbit sera 813 and 1009 , were found in the $20 \%$ sucrose. Dialysis against glycine $\mathrm{HCl}, \mathrm{pH} 2.2$, did not dissociate any smaller molecular weight species of thyroid stimulator or antiidiotypic activity to be found in the $10 \%$ sucrose, although the activity of serum 1009 was lost with the acid treatment. In the same centrifugation, over $90 \%$ of ${ }^{125}$ I-TSH was recovered in $10 \%$ sucrose after dissociation from anti-TSH by dialysis against acidic buffer, whereas $71 \%$ of the total hormone was recovered with the immunoglobulin in $20 \%$ sucrose when the complex was not acidified (Table I).

TSH dissociated by acid from an immune complex would not be detected by the binding of ${ }^{125} \mathrm{I}$-anti-TSH using staphylococcal protein $A$, since mouse $\operatorname{IgG}_{1}$ binds poorly to protein

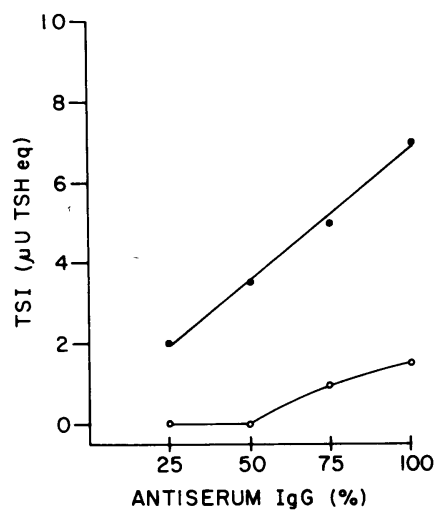

Figure 3. IgG from rabbits 13 (॰, day 160$)$ and $9(0$, day 225) were diluted with varying quantities of preimmunization IgG from the same rabbits. TSI activity is shown on the ordinate as microunits of TSH eq per $1.5 \mathrm{mg}$ of IgG. The proportion of the original immunized serum IgG is shown on the abscissa. A smooth doseresponse curve was seen with each of the sera. 
Table I. Effects of Acid Dissociation and

Ultracentrifugation on Rabbit TSI

and Antiidiotypic Activity to Anti-TSH

\begin{tabular}{|c|c|c|c|c|c|}
\hline \multirow[b]{2}{*}{ Rabbit } & \multirow[b]{2}{*}{ Sucrose } & \multicolumn{2}{|l|}{ pH 7.3} & \multicolumn{2}{|l|}{ pH 2.2} \\
\hline & & TSI & Anti-ID & TSI & Anti-ID \\
\hline & $\%$ & $\mu U T S H e q$ & $\%$ & $\mu U T S H e q$ & $\%$ \\
\hline \multirow[t]{3}{*}{813} & 10 & 0 & 1.7 & 0 & 2 \\
\hline & 20 & 8.0 & 15.8 & 5.5 & 12.1 \\
\hline & $10+20$ & & & & 6.1 \\
\hline \multirow[t]{5}{*}{1009} & 10 & 0 & 1.7 & 0 & 0.2 \\
\hline & 20 & 5.5 & 9.1 & 0 & 0.6 \\
\hline & $10+20$ & & & & 1.7 \\
\hline & & ${ }^{125} \mathrm{I}-\mathrm{TSH}$ & & & \\
\hline & & $c p m$ & $\%$ & cpm & $\%$ \\
\hline \multirow{2}{*}{$\begin{array}{l}\text { TSH-anti-TSH } \\
\text { complexes }\end{array}$} & 10 & 5,889 & 29 & 20,262 & 92 \\
\hline & 20 & 14,235 & 71 & 2,241 & 8 \\
\hline
\end{tabular}

Anti-ID, antiidiotypic activity.

A. Therefore, a portion of each of the acidified sucrose layers was recombined to allow for the hypothetical association of TSH with rabbit anti-TSH before assay with the mouse monoclonal anti-TSH. If TSH had been present in the $10 \%$ sucrose layer, this procedure would have made the binding value of the recombined layers greater than that of the acidified $20 \%$ sucrose alone. Such was not the case. The recombined layers of serum 813 showed less binding activity. None of the values for binding of monoclonal anti-TSH for serum 1009 was significantly different from normal rabbit serum controls.

The TSI levels in the animal sera appeared unrelated to the general health of the animals. Specifically, there was no relationship to their weight.

Antimembrane assay. Rabbit sera obtained before immunization and at $170 \mathrm{~d}$ were assayed for their ability to bind to TM. Sera obtained before immunization from 23 rabbits bound $2.6 \pm 0.8 \%$ (mean \pm SD) of added ${ }^{125}$ I-staphylococcal protein A. All of the animals' sera contained more TM-binding activity when samples obtained at day 170 were assayed (Table II).

Rabbit sera with detectable TSI content $(>2.0 \mu \mathrm{U}$ TSH eq) always contained large amounts of TM-binding activity, and the sera that were most active as TSIs also had large amounts of TM-binding activity. We directly compared TSI and TM-binding activities in serum from rabbits 9 and 13 for

Table II. Binding of Immunoglobulins to Human TM

\begin{tabular}{lccc}
\hline & $n$ & $\begin{array}{l}\text { Percent of } \\
\text { 125I-protein A }\end{array}$ & $\begin{array}{l}P \text { vs. } \\
\text { preimmunization }\end{array}$ \\
\hline & & mean $\pm S D$ & \\
Preimmunization & 23 & $2.6 \pm 0.8$ & \\
$\begin{array}{l}\text { 170th d } \\
\text { bTSH }\end{array}$ & 4 & $8.5 \pm 4.1$ & $<0.001$ \\
hTSH & 6 & $6.2 \pm 2.6$ & $<0.001$ \\
hTSH $\beta$ & 6 & $5.3 \pm 1.6$ & $<0.001$ \\
hSA & 6 & $10.0 \pm 3.0$ & $<0.001$ \\
& & & \\
\hline
\end{tabular}

seven different bleedings. The correlation coefficient between the two assays was 0.73 for rabbit 9 and 0.56 for rabbit 13 , so the two antibody activities were related.

TM binding was not specific for antithyroid antibodies, since rabbit antibodies to hSA also bound well to TM.

Anti-TSH. Large amounts of anti-TSH were found in serum assayed $40 \mathrm{~d}$ after the first immunization (Table III). Anti-TSH activity gradually increased as immunization continued. The largest amounts of hTSH-binding activity were in animals immunized with hTSH, and titers were only a little lower in animals immunized with hTSH $\beta$. Rabbits immunized with bTSH all developed significant amounts of hTSH-binding activity which, however, were approximately 100 -fold less than in the animals immunized with hTSH. No hTSH-binding activity was demonstrated in animals immunized with hSA. The lack of correlation between TSI and anti-TSH is illustrated by comparison of Table III with Fig. 1. TSI activity reached a maximum at day 160 and then declined, whereas anti-TSH activity continued to increase despite the fact that there were only two immunizations between day 40 and day 160 .

$T_{4}$ concentrations. $T_{4}$ concentrations in the serum of the rabbits were measured on seven occasions during the first 170 $\mathrm{d}$ of the experiment (Table IV). Analysis of variance revealed no significant variations due to either immunization or time of bleeding. In addition, there was no relationship between $T_{4}$ levels and anti-TSH or TSI activity in the rabbit sera. There was no evidence of hypothyroidism in any of the animals.

\section{Discussion}

We immunized animals with both hTSH and bTSH. Crude globulin fractions from these antisera were able to produce thyroid-stimulating effects in the thyroid cell bioassay. Approximately one-third of the animals immunized with TSH developed TSI activity $>2$ SD above the mean of nonspecifically immunized animals. This biological effect, however, did not occur with the serum from all of the animals.

The most striking examples of TSI activity were found with sera from animals immunized with crude bTSH. Immunoglobulins from these same sera bound a monoclonal mouse anti-hTSH, and the two activities correlated strongly, suggesting that the immunoglobulins were the same.

TSI activity in many of the sera was relatively weak. We considered the possibility that some nonspecific disturbance of the thyroid cell induced by antibodies unrelated to the TSH receptor may produce thyroid stimulation. This seems not to have been the case, however, since there was an excellent doseresponse relationship between the amount of TSI-containing antiserum and the thyroid cell bioassay response. In addition,

Table III. Anti-TSH Activity of Immunized Rabbit Sera*

\begin{tabular}{lccccc}
\hline & \multicolumn{6}{c}{ Days } & & & \\
\cline { 2 - 6 } Antigen & 40 & 160 & 170 & 225 & 245 \\
\hline hTSH & $20 \pm 6$ & $5.9 \pm 2.1$ & $5.1 \pm 1.5$ & $5.3 \pm 0.7$ & $5.5 \pm 1.2$ \\
hTSH $\beta$ & $190 \pm 90$ & $19 \pm 4$ & $15 \pm 4$ & $18 \pm 4$ & $10 \pm 2$ \\
bTSH & $>900$ & $660 \pm 80$ & $450 \pm 100$ & $510 \pm 100$ & $550 \pm 140$ \\
\hline
\end{tabular}

Mean \pm SEM. ${ }^{*}$ Nanoliters required to bind $50 \%$ of added ${ }^{125} \mathrm{I}-\mathrm{hTSH}$. 


\begin{tabular}{|c|c|c|c|c|c|c|c|c|}
\hline \multirow[b]{2}{*}{ Antigen } & \multicolumn{8}{|l|}{ Days } \\
\hline & 0 & 20 & 30 & 45 & 55 & 70 & 160 & 170 \\
\hline & $\mu g /$ liter & $\mu g /$ liter & $\mu \mathrm{g} / \mathrm{liter}$ & $\mu g /$ liter & $\mu g /$ liter & $\mu g / l i t e r$ & $\mu g /$ liter & $\mu g / l i t e r$ \\
\hline hTSH & $2.7 \pm 1.2$ & $2.1 \pm 1.9$ & $3.0 \pm 2.7$ & $4.8 \pm 2.2$ & $3.2 \pm 2.0$ & $1.8 \pm 0.6$ & $3.3 \pm 1.9$ & $3.0 \pm 2.0$ \\
\hline hTSH $\beta$ & $2.7 \pm 1.5$ & $1.1 \pm 0.6$ & $2.1 \pm 0.9$ & $4.4 \pm 2.0$ & $2.3 \pm 1.4$ & $1.5 \pm 1.2$ & $2.0 \pm 1.4$ & $1.6 \pm 1.6$ \\
\hline bTSH & $3.0 \pm 0.8$ & $2.4 \pm 1.5$ & $2.1 \pm 0.6$ & $4.4 \pm 1.5$ & $2.9 \pm 0.9$ & $1.8 \pm 1.1$ & $3.4 \pm 1.0$ & $3.2 \pm 1.4$ \\
\hline $\mathrm{hSA}$ & $2.8 \pm 1.8$ & $2.0 \pm 1.2$ & $2.9 \pm 0.7$ & $3.8 \pm 2.4$ & $3.7 \pm 1.7$ & $2.1 \pm 1.4$ & $3.1 \pm 1.1$ & $4.1 \pm 1.2$ \\
\hline
\end{tabular}

Mean \pm SD.

immunoglobulin binding to TM was noted. One would not expect an immunization response to such highly purified antigens as hTSH and hTSH $\beta$ to produce antibodies to nonspecific membrane components, so it is reasonable to speculate that these antibodies may be binding to the TSH receptor.

The binding of anti-hSA antibodies to the TM serves to emphasize the nonspecificity of the membrane preparation that undoubtedly contains human serum protein.

One of the possibilities we entertained, that the thyroidstimulating and antiidiotypic activities were due to TSH injected for immunization, seemed unlikely since the most prominent evidence of thyroid-stimulating activity was found in serum more than $3 \mathrm{mo}$ after the last injection of the immunizing antigen. In addition, little or no TSH should have been found in the washed $33 \%$ saturated ammonium sulfate precipitate used for the thyroid cell bioassay. On the other hand, TSHanti-TSH immune complexes may well have been found in such a fraction, and it was possible that immune complexes of rabbit TSH with anti-TSH might explain the findings. In a series of experiments reported about a decade ago, we felt we had evidence for exactly that type of response $(18,19)$. Thyroid-stimulating activity was found in the sera of animals immunized with TSH. Many of those animals, but not necessarily those whose sera had thyroid-stimulating activity, were rendered hypothyroid by immunization, and TSH-anti-TSH immune complexes prepared in vitro imitated many of the features of the sera obtained from the animals. In each case, however, it is possible to interpret these earlier results as due to an antiidiotype mimicking TSH or a complex of such an antiidiotype with anti-TSH.

In contrast, during this series of immunizations, none of the animals became hypothyroid. The thyroid-stimulating activity increased at a time remote from immunization rather than soon afterward. The most telling point, however, is that centrifugation of acid-treated globulins in a manner that successfully dissociated and separated TSH from TSH-antiTSH immune complexes did not liberate any TSI or antiidiotypic activity to the top portion of a density gradient.

Demonstration of the TSI activity and the antiidiotypic activity in the globulin fraction of rabbit sera fulfills a prediction that such activities would be found if an antiidiotype to antiTSH appeared after immunization with TSH and if that antiidiotype did indeed possess a mirror image binding site that fit the TSH receptor. The serum activities were found some 3 mo after immunization, as would be expected with an antiidiotypic response. The lack of correlation with anti-TSH is not unexpected. There is little information available about the possible persistence of such a response. Unfortunately, immunization of the rabbits again at day 160 produced the predicted response, i.e., an increase in anti-TSH accompanied by a decrease in the antiidiotypic response.

Antiidiotypic antibodies to anti-TSH were previously obtained by Islam and co-workers who immunized rabbits with rat anti-TSH (20). One of the sera obtained inhibited TSH binding to TM and had both inhibitory and stimulatory effects on thyroidal adenyl cyclase, depending on the experimental conditions (20). Current studies have demonstrated that an antiidiotype with thyroid-stimulating activity can arise as an autoantiidiotype in animals immunized with TSH. Whether TSI production by this means is relevant to Graves' hyperthyroidism, of course, is unknown. These animals did not develop any abnormalities in thyroid function as a result of this serum activity. $T_{4}$ concentration in the serum did not rise, and there was no evidence of weight loss or other illness that may be interpreted as hyperthyroidism in the animals.

\section{Acknowledgments}

Our thanks to Dr. Sebastiano Filetti for helpful discussions. We also thank Dr. David Solomon for his advice and careful reading of the manuscript. Michelle Pepitone provided excellent technical assistance, and Hilda Dornfest deserves thanks for typing the manuscript.

We wish to ackowledge grant support as follows: Dr. Beall received grant AM 23070 and Dr. Chopra grant AM 16155 from the National Institute of Arthritis, Diabetes, and Digestive and Kidney Diseases (NIADDK), National Institutes of Health. Dr. Rapoport received grant AM 19289 from the NIADDK and a grant from the Veterans Administration Research Service. We also wish to acknowledge the gift of hTSH and hTSH $\beta$ from the National Hormone and Pituitary Program of the NIADDK and the University of Maryland.

\section{References}

1. Chopra, I. J., and D. H. Solomon. 1983. Pathogenesis of hyperthyroidism. Annu. Rev. Med. 34:267-281.

2. Pinchera A., G. F. Fenzi, E. Macchia, L. Bartalena, S. Mariotti, and F. Monzani. 1982. Thyroid-stimulating immunoglobulins. Horm. Res. (Basel). 16:317-328.

3. Jerne, N. K. 1974. Towards a network theory of the immune system. Ann. Immunol. 125:373-389.

4. Sege, K., and P. A. Peterson. 1978. Use of anti-idiotypic antibodies as cell-surface receptor probes. Proc. Natl. Acad. Sci. USA. 75:2443-2447.

5. Schreiber, A. B., P. O. Couraud, C. Andre, B. Vray, and A. D. Strosberg. 1980. Anti-alprenolol anti-idiotypic antibodies bind to $\beta$ adrenergic receptors and modulate catecholamine-sensitive adenylate cyclase. Proc. Natl. Acad. Sci. USA. 77:7385-7389.

6. Marasco, W. A., and E. L. Becker. 1982. Anti-idiotypic antibody 
against the formyl peptide chemotaxis receptor of the neutrophil. $J$. Immunol. 128:963-968.

7. Schechter, Y., R. Maron, D. Elias, and I. R. Cohen. 1982. Autoantibodies to insulin receptor spontaneously develop as antiidiotypes in mice immunized with insulin. Science (Wash. DC). 216: $542-545$.

8. Beall, G. N., and S. R. Kruger. 1982. Binding of ${ }^{125}$ I-human TSH by gamma globulins of sera containing thyroid-stimulating immunoglobulin (TSI). Life Sci. 32:77-83.

9. Biro, J. 1981. Specific binding of thyroid-stimulating hormone by human serum globulins. J. Endocrinol. 88:339-349.

10. Biro, J. 1981. TSH binding by globulins from patients with Graves' disease. Endocrinol. Exp. 15:145-153.

11. Rapoport, B., F. S. Greenspan, S. Filetti, and M. Pepitone. 1984. Clinical experience with a human thyroid cell bioassay for thyroid-stimulating immunoglobulin. J. Clin. Endocrinol. Metab. 58: 332-338.

12. Rapoport, B., S. Filetti, N. Takai, P. Seto, and G. Halverson. 1982. Studies on the cyclic AMP response to thyroid stimulating immunoglobulin (TSI) and thyrotropin (TSH) in human thyroid cell monolayers. Metab. Clin. Exp. 31:1159-1167.

13. Manşon, L. A., E. Verastegui-Cerdan, and R. Sporer. 1979. A quantitative disc radioimmunoassay for antibodies directed against membrane-associated antigens. In Lymphocyte Hybridomas. F. Melchers and M. Potter, editors. Springer-Verlag, Berlin. 232-234.
14. Beall, G. N., I. J. Chopra, D. H. Solomon, W. J. Irvine, and S. R. Kruger. 1979. Studies of the TSH radioreceptor assay. Acta Endocrinol. 90:217-226.

15. Pekary, A. E., J. M. Hershman, and A. F. Parlow. 1975. A sensitive and precise radioimmunoassay for human thyroid-stimulating hormone. J. Clin. Endocrinol. Metab. 41:676-684.

16. Geha, R. 1983. Presence of circulating anti-idiotype bearing cells after immunization with tetanus toxoid (TT) and inhibition of anti-TT antibody synthesis by auto-anti-idiotypic antibody. J. Immunol. 130:1634-1639.

17. Chopra, I. J. 1972. A radioimmunoassay for measurement of thyroxine in unextracted serum. J. Clin. Endocrinol. Metab. 34:938947.

18. Beall, G. N., I. J. Chopra, D. H. Solomon, J. G. Pierce, and J. S. Cornell. 1973. Neutralizing and non-neutralizing antibodies to bovine thyroid-stimulating hormone and its subunits. J. Clin. Invest. 52:2979-2985.

19. Beall, G. N., I. J. Chopra, D. H. Solomon, J. G. Pierce, and J. S. Cornell. 1973. The effects on rabbits of immunization with bovine thyroid-stimulating hormone and its subunits. J. Clin. Invest. 52:29862992.

20. Islam, M. N., B. M. Pepper, R. Briones-Urbina, and N. R. Farid. 1983. Biological activity of anti-thyrotropin anti-idiotypic antibody. Eur. J. Immunol. 13:57-63. 